\title{
Optimization of Integrated Justice System through Management Approach
}

\author{
Bambang Dwi Baskoro ${ }^{1}$, Hartiwiningsih ${ }^{2}$, Hari Purwadi ${ }^{3}$ \\ \{bambangdwibaskoro@gmail.com ${ }^{1}$, hartiwi50@yahoo.com², hpurwadie@gmail.com ${ }^{3}$ \} \\ Doctoral Program, Faculty of Law, Universitas Sebelas Maret, Surakarta, Indonesia
}

\begin{abstract}
The criminal justice system is a large organization which consists of a lot of big built up organization. Criminal justice system performance does not have the following values, such as fragmentary and institution-centered; pointing at each other, the sector ego, and so on. It means there are some parts of the criminal justice system that cannot be reached. Optimizing activities of the criminal justice system can be reached by using management approach, such as (1) Planning; (2) Organizing; (3) Leadership; and (4) Controlling human resources organizational development.
\end{abstract}

Keywords: Criminal Justice System, Integrated Justice System

\section{Introduction}

Based on Article 1 Paragraph (3) of the 1945 Constitution of Republic of Indonesia, in state law, basically the supreme leader of the state is not human, but constitution which reflects the supreme law. The recognition of the law as the holder of supreme power places the judicial power of judiciary power as a significant power. Judicial power contains the meaning of power in the enforcement of criminal law, including the power to conduct a case investigation, the power to prosecute a case, the power to try a case, and the power to impose the criminal sanction imposed by the Court. (1) On the other hand, Saparinah Sadli, as quoted by Barda Nawawi Arief, states that crime or criminal behavior is a form of deviant behavior that is always present and inherent in every form of society, thus there is a society that can avoid evil. (2)Perilaku menyimpang tersebut merupakan suatu realitas social. (3) Barda Nawawi Arief states that crime as a social problem is not only a problem for a particular society (national) but also a problem faced by all people in the world. Quoting Seiichiro Ono's opinion, evil is a "universal phenomenon." (2) Wirjono Prodjodikoro considers crime or offense as a violation of norms in three other legal areas, namely civil, constitutional, and government administrative law, which the legislator responds to with a criminal penalty. (4)

The development of technology in telecommunications field establishes the era of the end of timelines because it has enabled a person or a group of people from one part of the world to connect with other person or group from other parts of the world without any time, transportation, accommodation, and considerable costs constraints. (5) Economic activities of business practitioners who always pursue profit generates a type of crime with an economic dimension or what is so-called as economic crimes or business crimes. (6) The development of science and technology also lead to what is called Cyber Crime or cyberspace or virtual space offense, a new dimension of high tech crime, a new dimension of transnational crime, and a new dimension of white-collar crime. (7)

The increasing quantity and quality of crime in most countries is reaffirmed at the fifth 
UN Congress of 1975 in Geneva; thus in this congress, there are particular topics concerning: (1). The changes in shape and dimensions of crime, both transnational and national; and (2) the economic and social consequences of crime. (The cost of a hidden crime is higher than the cost of a known crime because of the cost of a crime that is known as "the tip of the iceberg").(2) Efforts to overcome crimes with the criminal law are still frequently questioned, so the debate over the use of criminal law in tackling the problem of evil raises the groups of pros and cons and in the middle between the pros and cons. (8).

Related to management aspect, according to G.R. Terry, as cited by M. Anton Athoillah, management is a typical process consisting of planning, organizing, mobilizing and controlling actions to determine and to achieve goals through the utilization of human and other resources. (9) In the United Nations Congress Resolution on the Eighth Prevention of Crime and the Treatment of Offenders, held in Havana, Cuba in 1990, it is said in Item 19 on Management of Criminal Justice and Development of Sentencing Policies. In its consideration it is said as follows:

(a) Only if the criminal justice system is well managed can rational change be made to improve the situation;

(b) Inadequate management of the criminal justice system can result in certain practices, such as long delays before trial, that may create injustices for the person whose cases are being processed by the system;

(c) Satisfactory relations between different agencies of the criminal justice system can contribute to the effective allocation of resources. (10)

The system approach to the judicial administration mechanism sees that the existing criminal justice system in Indonesia has not performed as an integrated, independent, authoritative state institution and is not served as a place for seeking and obtaining competent judiciary. For instance, Detention of KPK Commissioners, Bibit Samad Riyanto and Chandra Hamzah, which was conducted by the Police because the allegations of both have committed an abuse of authority due to a bribe. (11) In the event, it shows the existence of a sector ego and no coordination between POLRIand KPK.

\section{Experimental Details}

This research used a normative approach. Its operation was carried out according to the positivist paradigm. The research was contracted with two strategies, namely library research and case study. The secondary data were obtained through library research and legal documents - secondary law materials, consisting of books. The primary data were obtained through field research conducted by observations and interviews in PT Yogyakarta, PN Yogyakarta, and the supreme court. The analysis is also carried out quantitatively by tabulating incoming data obtained from interviews with respondents and data obtained from the relevant agencies to facilitate a qualitative analysis with the support of related literature. It is done qualitatively because the data relevant to the research material is inventoried and then critically reviewed with positive law norms.

\section{Findings}

The criminal justice system is an organization that becomes the main container of 
judicial management (still partial). The criminal justice system under normal circumstances is a criminal justice system without seeing the Corruption Court as a separate criminal justice system having its characteristics, while the criminal justice system in exceptional circumstances is a criminal justice system in which there is a Corruption Court as a separate criminal justice system. ${ }^{1}$

The manager is the leader of the criminal justice system. In the criminal justice system as an organization, there are sub-sub systems in the form of organizations with their leaders as the manager. Then, who is the manager of the entire organization (top manager)? There is no one. This means that the criminal justice system as an organization does not have a manager (top manager) or considered to be their ways.

Rules of the game in organizations are called the Articles of Association (Anggaran Dasar) and Bylaws (Anggaran Rumah Tangga) (still partial). There is no rules of the game as a whole in organizations which referred to as $\mathrm{AD} / \mathrm{ART}$ of the organization referred to as the Indonesian Criminal Justice System (Indonesia), as there is no regulation for the whole organization (Indonesian criminal justice system) which consists of institutions that are supporting units of the criminal justice system (the existing agencies within the criminal justice sub-sub systems, the organizational goals which were set previously (still partial).

The purpose of the organization is not written in the legislation, either in the Law of Judicial Power, Criminal Procedure Code, or institutional/organizational/institutional laws of each subsystem of the criminal justice system. Planning contains various programs to be implemented (still partial). Direction gives way to the existing human resources within the organization (still partial). The techniques and mechanisms for the implementation of organizational activities, which in this case is the organizational structure of each institution is a part of the sub-subsystem of the criminal justice system and the mechanism of settlement of cases (still partial); (8) supervision of all organizational activities so as not to deviate from the established plan (still partial). Monitoring all organizational activities is done to prevent deviation of the plans that have been set. Supervision is the implementation of a control function. Supervision is the task of managers (top managers, middle managers, and first-line managers). (12)In this case, there is internal and external control. Also, it needs facilities, infrastructure, evaluation, and others.

\section{Conclusion}

Using the management approach of H.M. Anton Athoillah, there is an interconnected activity, which consists of: (a). The criminal justice system is the (large) organization that becomes the primary container of the existence of judicial managers; (b) there are only managers of small organizations and no top managers for the whole organization; (c) there are rules of game or $\mathrm{AD} / \mathrm{ART}$ of each small organization and there is no AD/ART for the entire organization; (d) the purpose of the criminal justice system has not been established as an organizational objective; (e). Planning in which various programs are being implemented, directed at sizeable organizational planning; (f) Partial human resource directing (in small organizations) is diverted to the direction of human resources in large organizations; (g). Techniques and mechanisms for the implementation of organizational activities (partial) are directed to the mechanisms for the implementation of extensive

\footnotetext{
1 The Corruption Court has coordination and supervisory function assigned to KPK. This is different from the general court of law (under the Criminal Procedure Code), Juvenile Court, Human Rights Court, and the Fisheries Court.
} 
organizational activities; (h). Supervision is needed for all organizational activities so as not to deviate, which may include internal and external monitoring; (i). The facilities and infrastructure have supported the implementation of the organization's activities; (j) .personal placement by the expertise or professionalism of their respective occupations; (k). The ultimate responsibility of all activities that have been carried out by the duties and obligations of the personal organization to top managers and top managers to be responsible to the people.

\section{References}

[1] B. N. Arief. Kapita Selekta Hukum Pidana Tentang Sistem Peradilan Pidana Terpadu. Semarang: Badan Penerbit UNDIP. 2007

[2] B. N. Arief, Kebijakan Legislatif dalam Penanggulangan Kejahatan dengan Pidana Penjara. Semarang: CV. Ananta; 1994

[3] I. S. Susanto, "Membangun Kriminologi yang Bercirikan Indonesia," Masalah Hukum, Vol. XIII(3):12, 1988

[4] W. Prodjodikoro, Tindak-tindak Pidana Tertentu di Indonesia. Bandung: Refika Aditama; 2010.

[5] A. Hidayat. Menegaskan Kembali Peran Negara di Tengah Melemahnya Kedaulatan Negara di Era Global. In: Bunga Rampai : Potret Penegakan Hukum di Indonesia,. Jakarta: Komisi Yudisial Republik Indonesia; p. 22-3. 2009.

[6] N. S. P. Jaya, Hukum dan Hukum Pidana di Bidang Ekonomi. Semarang: Badan Penerbit Undip; 2014

[7] B. N. Arief. Tindak Pidana Mayantara, Perkembangan Kajian Cyber Crime di Indonesia. Jakarta: Raja Grafindo Persada; 2006

[8] B. N. Arif, Muladi, Teori-teori dan Kebijakan Pidana. Bandung: Alumni, 1984.

[9] M. A. Athoillah. Dasar-dasar Manajemen. Bandung: Pustaka Setia, 2010.

[10] R. Atmasasmita, Sistem Peradilan Pidana, Perspektif Eksistensialisme dan Abolisionisme. 1996

[11] Media Indonesia: Tuesday 3 November 2009, Suara Merdeka : Thursday 10 September 2009, Kompas : Friday 30 Oktober 2009.

[12] R. L. Daft, New Era of Management, Cengage Learning, New York, USA, Terjemahan Tita Maria Kanita, Era Baru Manajemen. j: Salemba Empat; 2010. 